\title{
The Politics of Child Abuse
}




\section{The Politics of Child Abuse}

Nigel Parton

Macmillan Education 
ISBN 978-0-333-36317-1 ISBN 978-1-349-17830-8 (eBook)

DOI 10.1007/978-1-349-17830-8

(C) Nigel Parton 1985

Softcover reprint of the hardcover 1st edition 1985

All rights reserved. For information, write:

St. Martin's Press, Inc., 175 Fifth Avenue, New York, NY 10010

Published in the United Kingdom by Macmillan Publishers Ltd.

First published in the United States of America in 1985

ISBN 978-0-312-62675-4

Library of Congress Cataloging in Publication Data

Parton, Nigel

The politics of child abuse.

Bibliography: $p$.

Includes index.

1. Child abuse-United States. 2. Family policyUnited States. I. Title.

$\begin{array}{llll}\text { HV741.P37 } & 1985 & 362.7^{\prime} 044 & \text { 84-26276 }\end{array}$

ISBN 978-0-312-62675-4 
For Laura and Kate 


\section{Contents}

List of Figures and Tables

Preface

viii

ix

PART ONE: THE HISTORY

1. Child Abuse and the Sociology of Social Problems

2. Ghildren as Victims: Gruelty and Neglect in History

3. The Discovery of the 'Battered Baby'

4. The Social Reaction to Maria Colwell

5. Policy Developments and Practice Issues

PART TWO: A GRITIQUE

6. Child Abuse as Disease

7. Poverty, Social Structure and Child Abuse

8. Reformulating Policy and Practice 


\section{List of Figures and Tables}

\section{FIGURES}

Figure 4.1 Thresholds of societal tolerance

Figure 4.2 The Violent Society: convergence of themes

\section{TABLES}

Table 1.1 Dilemmas of social policy and professional response with children and families

Table 1.2 Alternative child abuse ideologies

Table 5.1 Place of safety orders 1972-6

Table 5.2 Number of children removed to a place of safety during the year 1 April to 31 March for England, 1977-80

Table 5.3 Wardship: number of originating summons 1951-81

Table 5.4 Wardship: new references and total number of references to the Official Solicitor 


\section{Preface}

My interest in writing this book has grown out of my experiences as a generic social worker in a social services department in the early to mid 1970s. The department was undergoing various traumas and readjustments resulting from the double reorganisation following Seebohm and local government reorganisation. My colleagues and I were attempting to cope with the rapid changes in our role and workload and the changing demands and expectations made of us by both our clients and the wider community.

However, the period was punctuated by an event which generated enormous interest in, and debate about, social work and social workers, and which seemed of a different order to anything that had happened before - certainly in recent history. It felt as if the death of Maria Colwell and the subsequent inquiry had an impact on social work well beyond the more specific concerns about protecting children from cruel parents, a responsibility which child care officers were well accustomed to.

Not only did it seem that social workers were being pilloried - particularly in the media - but that we were being asked to get involved in and take responsibility for a problem which was called variously 'battered babies', 'non-accidental injury', or 'child abuse', and which was qualitatively different from anything that social workers had dealt with before. It seemed that a new social problem had been discovered which required new skills, new forms of intervention and new organisational arrangements to deal with it. Throughout there was a pervasive fear that the circumstances surrounding the death of Maria Colwell could have happened to any of us. It was as if 


\section{x Preface}

the optimism that had been so evident at the beginning of the decade was dealt a fatal blow by one dramatic event, and that we were being asked to re-think our priorities and practice in fundamentally different ways.

However, I had an uneasiness about what was happening to both clients and social workers. I was especially concerned that the nature of this new problem did not seem as clear-cut and straightforward as was suggested in most of the training manuals and guidelines. Nor was I convinced that many of the new policies and practices introduced were as humane as was assumed. They seemed to have unintended consequences which were deleterious for everyone involved.

Increasingly I felt the need for a more critical analysis of what was happening in a period of rapid change and high anxiety, in the hope of formulating new perspectives. First, it seemed important to look behind these events in order to understand my own experiences. Then, if we could establish why and how we came to this situation, we could begin to develop new ideas and practices.

Part One is primarily concerned with looking at the way in which child abuse was discovered, and the political processes whereby it was defined, brought to public attention and made the subject of state intervention. Briefly the argument is that the way the problem has been socially constructed has been based on a very particular set of assumptions and explanations. The medical model with its emphasis on individual 'disease', 'treatment', 'identification' and 'prevention' has been dominant. This has been crucial in influencing what we do about the problem and the manner in which we do it. Nor has this been a chance development, for changes in the economy, the state and the wider society have been central, together with the intervention of certain professional, organisational and political interests.

Part Two critically analyses this model and demonstrates how it offers a very partial and inadequate explanation and consequently an inappropriate framework for policy and practice. Other explanations are offered, based on an explicitly social-structural position, which then inform an alternative model for policy and practice.

Perhaps because the problem of child abuse has only 
emerged in the last twenty years, most of the literature and policy and practice recommendations have been concerned to encourage welfare practitioners to act where previously they may not have done. In the process, the assumptions inherent in such developments have been left implicit, the theoretical underpinnings left untested and practice rarely evaluated. It is generally assumed that everyone agrees and knows what the problem is, it is just a question of identifying and doing something about it. In contrast, however, I argue that debates about the nature of child abuse and what to do about it are in essence not technical but political debates about the good society, and the relationship between the family and the state.

Chapter 1 sets out the theoretical framework on which the book is organised and explores the application of a sociological understanding of social problems to child abuse. Those less interested in the theoretical framework of the book could move on to the remainder without any great loss. Similarly, those most interested in the current policy issues and the application of this perspective to practice may wish to turn directly to Chapters 5 and 8.

The book has been trying to get out for a number of years and during that time and previously I have benefited from all kinds of advice and discussions from practitioners and academics. There are many I cannot mention because of space, but I would particularly like to thank Joan Court, Linda Davies, Robert Dingwall, Alfred White Franklin, Christine Hallett, Bill Jordon, Gerry Lavery, Chris Melotte, Revd Arthur Morton, Terry Norris, Jean Packman, Ken Plummer and Terry Thomas.

I have drawn on the energies of various library staff particularly those at Huddersfield Polytechnic, who have always remained good humoured for all my continual demands. Linda Barker, Sandra Lewis and Liz Tunaley have provided excellent typing help and students and colleagues in the social work section at the Polytechnic have always been supportive. More particularly they allowed me the time to write: without them the book would never have been completed. However, more than anyone Chris Parton has ensured that the book is as good as it is. She has lived with it from the outset, provided encouragement when times were bad and intellectual stimula- 


\section{xii Preface}

tion throughout, as well as critically commenting on every chapter. Similarly, she has taken far more than her fair share of household and child care responsibilities so that I could make progress.

I am very aware that the subject is an emotive one and that much of what I write may be seen as contentious. I am also aware that many issues are left untouched or dealt with only in the context of the general argument. It is therefore important to underline that I am fully responsible for what follows. 